(C) Copyright 2020: Editum. Servicio de Publicaciones de la Universidad de Murcia. Murcia (Spain) ISSN print edition: 0212-9728. ISSN online edition (http://revistas.um.es/analesps): 1695-2294. Online edition License Creative Commons 4.0: BY-SA

\title{
Social Support, Self-Esteem and Quality of Life among People Living With HIV/AIDS in Jammu \& Kashmir India
}

\author{
Mohammad Amin Wani
}

Lovely Professional University Jalandhar, Punjab (India)

\begin{abstract}
Título: Apoyo social, autoestima y calidad de vida entre las personas que viven con el VIH / SIDA en Jammu y Cachemira, India.

Resumen: Antecedentes. El objetivo principal del presente estudio fue evaluar el nivel de apoyo social, autoestima y calidad de vida entre las personas que viven con el VIH / SIDA en Jammu y el Estado de Cachemira de la India. Además, el estudio se esforzó por explorar la relación entre variables independientes y dependientes. Método: El estudio consiste en una muestra de 460 pacientes con SIDA seleccionados mediante una técnica de muestreo intencional, de ellos 177 (38.3\%) eran hombres, $283(61.5 \%)$ eran pacientes femeninas; 295 (64.1\%) estaban casados y 165 (35.9\%) no estaban casados. Las medidas incluyeron el Inventario de apoyo social enriquecido de Mitchell et al. (2003), la Escala de autoestima de Rosenberg (1965) y la Escala de calidad de vida de Sharma y Nasreen (2014). Para el análisis estadístico de los datos, la versión SPSS 20.0 aplicó la media, la desviación estándar, la distribución de frecuencia, la prueba $t$, el análisis de varianza unidireccional, el cuadrado de eta, el análisis de correlación y la prueba post hoc de Scheffe. Hallazgos: Los hallazgos ilustran que la mavoría de los pacientes tienen poco apoyo social, baja autoestima y mala calidad de vida; también revela que el apoyo social y la autoestima del paciente difieren según la edad, la ocupación, la duración de la enfermedad, el género y el estado civil. Sin embargo, su calidad de vida difiere solo por su edad, ocupación, duración de la enfermedad y estado civil. Además, el resultado muestra que el apoyo social y la autoestima se correlacionan positivamente con la calidad de vida.

Palabras clave: Apoyo social; Autoestima, Calidad de vida y VIH / SIDA.
\end{abstract}

\section{Introduction}

Since the inception of humankind, the man has been witnessed fatal diseases that have taken a substantial toll on them. History records diseases like, plague, smallpox, chicken pox, typhus fever, etc., that lived through populations like the proverbial scythe of old man time (Khurana, 1989). After 1980 a new monster has raised its head known as Acquired Immune Deficiency Syndrome (AIDS). It is a sexually transmitted disease like Syphilis, Candidiasis, Chlamydia, Gonorrhoea etc. This chronic disease affects patient's physical, psychological, and biological system. It is a lethal neuromedical disorder occurred by the retroviral virus known as human immunodeficiency virus (HIV) that impaired the functions of immune system, The virus mainly contaminates white blood cells (WBC) known as Cluster of Differentiation 4 (CD4), T helper cells, or monocytes. HIV is found in the patient's blood, semen, vaginal or rectal fluids, lymphocytes, cerebrospinal fluid, and breast milk. It is commonly transmitted from one to another by unprotected vaginal as well as anal sex with infected person and intravenous blood exposu-

* Correspondence address [Dirección para correspondencia] Dr. Mohammad Amin Wani. Khasipora (Near primary Health Center) Khore Sherabad, Pattan, Baramulla Jammu \& Kashmir, Pin Code: 193121 (India).E-mail: mypsyresearch@outlook.com,wanipsychology@gmail.com (Article received: 27-11-2018, revised: 14-2-2019, accepted: 2-7-2019)
Abstract: Background: The cardinal aim of the present study was to assess the level of social support, self esteem and quality of life among people living with HIV/AIDS in Jammu and Kashmir State of India. Further, the study strived to explore the relationship between independent and dependent variables. Method: The study consists a sample of 460 AIDS patients selected through purposive sampling technique, out of them $177(38.3 \%)$ were male, $283(61.5 \%)$ were female patients; 295 (64.1\%) were married and $165(35.9 \%)$ were unmarried. Measures included Enriched Social Support Inventory by Mitchell et al., (2003), Rosenberg's Self-Esteem Scale (1965) and Quality of Life Scale by Sharma \& Nasreen (2014). For the statistical analysis of data Mean, Standard deviation, Frequency distribution, ttest, one way analysis of variance, eta square, correlation analysis and Scheffe's post hoc test was applied by SPSS 20.0 version. Findings: The findings illustrated that majority of patients have poor social support, lower self-esteem and poor quality of life; also it reveals that patient's social support, and self-esteem differs by age, occupation, duration of illness, gender, and marital status. However their quality of life differs only by their age, occupation, duration of illness, and marital status. Further the result shows social support and self-esteem are positively correlated with quality of life. Keywords: Social Support; Self-Esteem; Quality of Life \& HIV/AIDS. re by sharing contaminated needles (Rom \& Markowitz, 2011).HIV/AIDS is the second contagious disease and sixth common cause of death in the world (WHO, 2017).

Since 1981, AIDS kills 39 million people, presently 36.7 million people are living with HIV/AIDS (PLWHA) among them 34.5 million are adults, 17.8 million are women, and 2.1 million are children's below 15 years old. As per HIV Sentinel Surveillance 2014-15 the Jammu and Kashmir state has $0.05 \%$ people living with HIV/AIDS. Till august 2017, 4288 HIV/AIDS patients are registered in ART centers. In ART center GMC Jammu out of 3797 registered HIV/AIDS patients only 2042 patients are alive (males 1035, females 862, TS/TG 3 and 142 children below 15 years) while as in SKIMS Srinagar $491 \mathrm{HIV} /$ AIDS patients were registered among them only 234 patients are alive (males 148, females 71 , TS/TG 1 and 14 children below 15 years). State also witnessed deaths of $886 \mathrm{HIV} /$ AIDS patients till august 2017; 600 patients are reported not came for treatment for consecutive three months (J\&KSACS, 2017).

AIDS influence the individual's psychological well being and quality of life. People living with AIDS are facing various problems in everyday life whether in their homes, work places, or in society. They have the feelings of loneliness, hopelessness, stress, generalized anxiety disorders. Therefore, social support is a critical issue to people living with HIV/AIDS. Due to stigma inclined to this disease, patients have fear of isolation, separation, job loss. Majority of the 
patients are hopeless, helpless; even sometimes they are isolated by family members and society. Due to this they are encountered by various psychological problems like grief, anxiety, stress, depression, suicidal ideations etc, therefore their quality of life is badly affected. Rigby \& Slee (1999) found suicidal ideations or suicides among AIDS patients are due to poor social support. Wani \& Sankar (2017) also reported that suicidal ideation is negatively correlated with social support and self esteem. Adewuya et al., (2007) revealed that most of the psychological problems among people living with HIV/AIDS are due to poor social support. Researchers also found that social support influences patient's quality of life (Nunes et al., 1995), and mental health (Nakimuli et al., 2011). Proper social support is significantly associated with lower depression (Debra \& Barbara, 2000), enhance one's self-esteem (Denissen, Pebke, Schmitt \& Aken 2008) and improve persons coping strategies (Cobb, 1976). Social support is positively correlated with quality of life (Wani \& Sankar, 2017a, Wani \& Sankar 2017b). As surmised by researchers AIDS influences the patients selfesteem, it also affects their quality of life. It is also found that HIV patients have lower self-esteem (Castrighini Gir, Neves, Reis, Galvão, \& Hayashido (2010); it is due to isolation, rejection, and the physiological consequences of illness (Van 2008). It influence health related quality of life (Shin, 2011), is positively associated with life satisfaction (Moksnes \& Espnes (2013). Quality of life significantly differs with occupation and duration of illness (Wani, 2018).Simultaneously low self-esteem is associated with anxiety, depression, hopelessness, and isolation (Reis, Santos, Dantas, \& Gir 2011; Cechim, \& Selli, 2007).Social consequences of HIV/AIDS such as fear of social stigma, isolation and discrimination negatively affects quality of life. People living with HIV/AIDS have various physiological; sociological as well as psychological problems which directly affect their quality of life which results suicidal ideations, suicidal tendencies even sometime commit to suicide.

\section{Objectives of the Study}

1. To assess the level of social support, self-esteem and quality of life among people living with HIV/AIDS in Jammu \& Kashmir.

2. To evaluate significant differences among independent variables (social support, and self-esteem) and dependent variable (quality of life) on the basis of demographic variables (age, gender, marital status, occupation and duration of illness).

3. To explore the relationship between the social support, self-esteem and quality of life.

\section{Hypotheses of the Study and variables}

1. There is significant difference found in patient's social support based on demographic variables.
2. There is significant difference found in patient's selfesteem based on demographic variables.

3. There is significant difference found in patients quality of life based on demographic variables.

4. Significant relationship is found between the social support, self-esteem and quality of life.

In the present study social support and self-esteem are taken as independent variables, whereas quality of life is dependent variable. However, age, gender, marital status, occupation and duration of illness are taken as demographic variables in the study.

\section{Methods}

\section{Participants}

The present study consists $24 \%$ HIV/AIDS population of Jammu and Kashmir State. Therefore the total participants were 460, selected from the population of 1864 HIV/AIDS patients (Alive on ART), through purposive sampling technique. Out of these 460 patients, 323 were selected from Antiretroviral Treatment Center (ART Center) Government Medical College (GMC) Jammu; 137 from ART center Sher-I-Kashmir Institute of Medical Sciences (SKIMS) Srinagar. Patients who met following criteria were selected:
A. Above the age group of 20 years.
B. Having the citizenship of Jammu and Kashmir State.
C. Registered in ART center in Jammu and Srinagar.
D. Hindu, Muslim, and Sikh patients.
E. Male and female patients.

\section{Instruments}

Enriched Social Support Inventory: The Enriched Social Support Inventory (ESSI) developed by Mitchell et al., (2003) was used for the assessment of social support among patients. This scale consists seven items; first six items have five responses viz. None of the time, A little of the time, Some of the time, Most of the time, and All the time. However the last item has only two responses 'Yes' and 'No' respectively. The scoring for first six statements sore 1, 2, 3, 4, 5, whereas for seventh statement it is 4 for ' 'Yes' and 2 for ' No' response respectively. The scale was found reliable through intra class correlation coefficient and Cronbach's Alpha methods and is found 0.94 and 0.88 respectively.

Rosenberg's Self-Esteem Scale: The self-esteem of the patient was measured by the Self-Esteem Scale constructed and standardized by Rosenberg (1965). The scale has 10 items with four alternatives from strongly agree to strongly disagree. The scoring for item 1, 3, 4, and 7 is 3 for strongly agree, 2 for agree, 1 for disagree, and 0 for strongly disagree. For item 2, 5, 6, 8, and 9 the scoring is reversed. The reliability of the scale was measured through test-retest method (0.82 to 0.85$)$. 
Quality of Life Scale: Quality of life scale standardized by Sarika Sharama and Nakhat Nasreen (2014) were used for the assessment of quality of life among HIV/AIDS patients. The scale consists of 42 items, out of them 34 are positive and 8 are negative items with three responses (Always, Seldom, and Never) respectively. Positive items are scored as 3, 2, 1 and negative items as $1,2.3$ respectively. The reliability of the scale 0.80 and .82 was found through Cronbach's alpha method, and the validity by face validity respectively.

\section{Procedure}

The study was conducted in Jammu and Kashmir State, India. For achieving the objectives of the study data was collected through purposive sampling method, from 460 HIV/AIDS patients registered in ART centre GMC (government medical college Jammu) and ART centre SKIMS (Sher-I-Kashmir Institute of Medical Sciences) Srinagar.

Patient's social support, self-esteem and quality of life were measured by (1) Enriched Social Support Scale, (2) Rosenberg's Self-Esteem Scale and (3)Quality of Life Scale. By getting the permission from the director Jammu and Kashmir State AIDS control society (JAKSACS) and medical officers of ART center Srinagar and Jammu. After getting the information about the patients from concerned authority proper rapport was established with the patient individually and was told the purpose of meeting. They were informed that their personal information like name, contact number etc., is not required and other the obtained information will be kept confidential. After the acceptance from the patient, demographic sheet which includes the personal details like age, gender, marital status, occupation and duration of illness, were given to the patient and were asked to give $(\boldsymbol{V})$ according by their choice. After that measuring instruments were given to the patients and were asked to give their responses. They were also told to read all the instructions carefully given in the questionnaire. Researcher helps illiterate and those patients who find difficulty in understanding statements; hence they give their responses. After that completed questionnaires were collected from patients and were thanked for their cooperation. Hence the primary data was collected.

\section{Statistical analysis}

For statistical analysis descriptive statistics (Mean, Standard deviation, Frequency distribution), Inferential statistics ( $\mathrm{t}$ test, one way analysis of variance), correlation analysis (Pearson's product moment method), eta square and Scheffe's post hoc test were used for data analysis, through SPSS 20.0 version.

To find the effect size of variables in ANOVA and t-test following formulas have been applied

Eta Square for ANOVA

$$
\eta^{2}=\frac{\text { SS Between }}{\text { SS Total }}
$$

Eta Square for t-test

$$
\eta^{2}=\frac{t^{2}}{t^{2}+(N 1+N 2-2)}
$$

\section{Findings}

The present study intended to find the self esteem, social relationships and the quality of life among people living with HIV/AIDS in the state of Jammu and Kashmir. The subjects were assessed on the variables under consideration and different patterns according to different demographic characteristics were also looked into. The results yielded by the study are discussed exhaustively in this section.

\section{Socio demographic characteristics of the study par- ticipants}

The sample (see Table 1) of four hundred sixty (460) HIV/AIDS patients were selected out of them $192(41.7 \%)$ was between the age group of 20 to 35 years, whereas 176 $(38.3 \%)$ between 36 to 50 years of age, and $92(20 \%)$ was more than 50 years of age respectively.177 (38.5\%) of AIDS patients were male and $283(61.5 \%)$ were female AIDS patients, and that of $295(64.1 \%)$ patients were married and $165(35.9 \%)$ patients were unmarried. Further out of total sample size 193 (42\%) of the HIV/ AIDS patients was unemployed, 141 (30.7\%) employed and 126 (27.4\%) businessman respectively. Regarding the duration of illness it was found that out $123(26.7 \%)$ patients have illness less than 1 year, whereas majority of the patients $212(46.1 \%)$ have 2 to 4 years duration of illness, $98(21.3 \%)$ patients have 5 to 6 years duration of illness, and very least $27(5.9 \%)$ patients have more than 6 years duration of illness.

Table 1. Distribution of HIV/AIDS patients with respect to age, gender, marital status, family type, family income, occupation and duration of illness.

\begin{tabular}{llll}
\hline Variable & Sub Variable & $\mathrm{N}$ & $\%$ \\
\hline \multirow{4}{*}{ Age } & 20 to 35 years & 192 & 41.7 \\
& 36 to 50 years & 176 & 38.3 \\
& Above 50 years & 92 & 20 \\
Gender & Total & $\mathbf{4 6 0}$ & $\mathbf{1 0 0}$ \\
& Male & 177 & 38.5 \\
& Female & 283 & 61.5 \\
Marital Status & Total & $\mathbf{4 6 0}$ & $\mathbf{1 0 0}$ \\
& Married & 295 & 64.1 \\
& Unmarried & 165 & 35.9 \\
\multirow{4}{*}{ Occupation } & Total & $\mathbf{4 6 0}$ & $\mathbf{1 0 0}$ \\
& Employed & 141 & 30.7 \\
& Businessman & 126 & 27.4 \\
& Unemployed & 193 & 42 \\
Duration of & Total & $\mathbf{4 6 0}$ & $\mathbf{1 0 0}$ \\
& Less than 1 Year & 123 & 26.7 \\
& 2 to 4 Years & 212 & 46.1 \\
& 5 to 6 Years & 98 & 21.3 \\
& More than 6 years & 27 & 5.9 \\
& Total & $\mathbf{4 6 0}$ & $\mathbf{1 0 0}$ \\
\hline
\end{tabular}


Levels of social support, self-esteem and quality of life

The research demonstrated that majority of HIV/AIDS patients $84.57 \%$ have low level, and very least $15.43 \%$ patients have high level of social support (see Table 2). Results also revealed that $51.52 \%$ patients have lower self esteem,
$38.69 \%$ have normal level, and $9.78 \%$ of patients have high levels of self esteem respectively. Further findings show that $26.52 \%$ patients have extremely low level of quality of life, whereas, $21.09 \%$ having above average level; $18.04 \%$ average level, $15.43 \%$ below average level, $14.57 \%$ low level, and very least $4.35 \%$ patients are having high level of quality of life.

Table 2. Distribution of patients with respect to levels of Social Support. Self-Esteem and quality of life.

\begin{tabular}{|c|c|c|c|c|}
\hline Variable & Levels & Scores & $\mathrm{N}$ & $\%$ \\
\hline \multirow[t]{3}{*}{ Social Support } & High Social Support & $28-34$ & 71 & 15.43 \\
\hline & Low Social Support & Below 27 & 389 & 84.57 \\
\hline & & Total & 460 & \\
\hline \multirow[t]{6}{*}{ Self-Esteem } & High Self-Esteem & $26-30$ & 45 & 9.78 \\
\hline & Normal Self-Esteem & $16-25$ & 178 & 38.69 \\
\hline & Lower Self-Esteem & Below 15 & 237 & 51.52 \\
\hline & & Total & 460 & \\
\hline & Extremely High Level & 103 and Above & - & - \\
\hline & High Level & $96-102$ & 20 & 4.35 \\
\hline \multirow[t]{6}{*}{ Quality of life } & Above Average Level & $88-95$ & 97 & 21.09 \\
\hline & Average/ Moderate Level & $77-87$ & 83 & 18.04 \\
\hline & Below Average Level & $69-76$ & 71 & 15.43 \\
\hline & Low Level & 61-68 & 67 & 14.57 \\
\hline & Extremely Low Level & Below 60 & 122 & 26.52 \\
\hline & & Total & 460 & \\
\hline
\end{tabular}

\section{Social Support}

The average social support was found to be 15.43, 19.16, and 19.26 , for the age group of 20 to 35 years, 36 to 50 years, and above 50 years respectively (see Table 3 ). Further it is unveiled that above 50 years old HIV/AIDS patients are having higher social support than below 50 year old patients. The research also indicates that 36 to 50 years old patients are having high social support than 20 to 35 years old patients. The significant $\mathrm{p}$-value (.000) reveals that social support differs by the age of the patients. Bennett, Perkins, Lane, Deer, Brater, \& Murray (2001) also reported that social support differs by the age.

It is also verified that social support differs by the occupational status of the HIV/AIDS patients. For employed, businessmen, and unemployed AIDS patients, the mean social support was found 19.94, 17.13, and 16.25 respectively. The employed patients are having higher social support than business doing and unemployed patients. Simultaneously, patients doing business are having higher social support than unemployed patients. Reza \& Siddegowda (2010) also found differences in social support among self-employed and other professions. Similarly, Roberts, Pearson, Madeley, Hanford, \& Magowan (1997) reported that unemployed have poorer social support than employed persons. Kong, Perrucci, \& Perrucci (1993); Yelin (1980) revealed that patients receive less social support due to higher levels of unemployment.

Patient's social support differs by duration of illness too. Patient's average social support was found to be 14.49, 17.80, 19.62, and 23.18, for patients with less than 1 year, 2 to 4 years, 5 to 6 years, and more than 6 years duration of illness respectively. The result justifies that patients having more than 6 years duration of illness have higher social support than those patients living with HIV/AIDS less than 6 years. Also, patients having 5 to 6 year duration of illness have higher social support than those patients having duration of illness less than 5 years. Findings also unveiled that patients having 2 to 4 years duration of illness have higher social support than those of having less than 1 year duration of illness. 
Table 3. Mean, standard deviation, f- value, Eta-square, and post hoc of Social Support by demographical variables of the HIV/ AIDS patients (N=460).

\begin{tabular}{|c|c|c|c|c|c|c|c|c|}
\hline Variable & Sub variables & $N$ & Mean & S.D & f-value & p-value & $\eta^{2}$ & post hoc \\
\hline & $20-35$ years $(a)$ & 192 & 15.43 & 6.40 & & \multirow{4}{*}{$<.001$} & \multirow{4}{*}{0.07} & \multirow{4}{*}{$\mathrm{c}>\mathrm{b}>\mathrm{a}$} \\
\hline \multirow{3}{*}{ Age } & $36-50$ years $(b)$ & 176 & 19.16 & 6.67 & \multirow{3}{*}{18.28} & & & \\
\hline & Above 50 years (c) & 92 & 19.26 & 6.82 & & & & \\
\hline & Employed (a) & 141 & 19.94 & 6.72 & & & & \\
\hline \multirow{4}{*}{ Occupation } & Businessmen (b) & 126 & 17.13 & 6.43 & \multirow{4}{*}{12.94} & \multirow{4}{*}{$<.001$} & \multirow{4}{*}{0.05} & \multirow{4}{*}{$\mathrm{a}>\mathrm{b}>\mathrm{c}$} \\
\hline & Unemployed (c) & 193 & 16.25 & 6.76 & & & & \\
\hline & Less than 1 Year (a) & 123 & 14.49 & 6.77 & & & & \\
\hline & 2-4 Years (b) & 212 & 17.80 & 6.24 & & & & \\
\hline \multirow[t]{2}{*}{ Duration of Illness } & 5-6 Years (c) & 98 & 19.62 & 6.79 & \multirow[t]{2}{*}{19.49} & \multirow[t]{2}{*}{$<.001$} & \multirow[t]{2}{*}{0.11} & \multirow[t]{2}{*}{$\mathrm{d}>\mathrm{c}>\mathrm{b}>\mathrm{a}$} \\
\hline & More than 6 years (d) & 27 & 23.18 & 5.16 & & & & \\
\hline
\end{tabular}

Further the eta square for the social support variable (see Table 4) was calculated pertaining to various demographic variables. The calculated eta square was found $\eta^{2}=0.07,0.05$ and 0.11 for age, occupation and duration of illness respecti- vely. In all demographic variables it is obvious that there is a small magnitude of effect between age, occupation and duration of illness with regard to social support.

Table 4. Mean, standard deviation, t-value, and Eta-square of Social Support by demographical variables of the HIV/ AIDS patients (N=460).

\begin{tabular}{|c|c|c|c|c|c|c|c|}
\hline Variable & Sub variables & $\mathrm{N}$ & Mean & S.D & t-value & $\mathrm{p}$-value & $\eta^{2}$ \\
\hline \multirow{2}{*}{ Gender } & Male & 177 & 19.33 & 7.29 & & \multirow{2}{*}{$<.001$} & \multirow{2}{*}{0.03} \\
\hline & Female & 283 & 16.55 & 6.31 & 4.33 & & \\
\hline \multirow{2}{*}{ Marital Status } & Married & 295 & 20.49 & 6.15 & & \multirow{2}{*}{$<.001$} & \multirow{2}{*}{0.31} \\
\hline & Unmarried & 165 & 12.48 & 4.63 & 14.57 & & \\
\hline
\end{tabular}

The average social support of male (19.33), female (16.55), married (20.49 and for unmarried (12.48) patients reveals that social support differs by gender and marital status too. The research also showed that male and married have higher social support than female and unmarried. Researchers like Rani (2016); Sharir, Tanasescu, Turbow, \& Maman (2007); Eberhart \& Hammen (2006) also found significant gender differences in social support. Riaz, Abid, Ullah, \& Khalid (2016) found that married people have high social support than unmarried.

The eta square to ascertain the effect size on social support by gender and marital status was evaluated which shows that there is small effect size of gender on social support $\left(\eta^{2}\right.$ $=0.03$ ) while the effect size of marital status on social support is medium $\left(\eta^{2}=0.31\right)$.

On the basis of above findings, it is revealed that patient's social support differs by age, occupation, duration of illness, gender, and marital status. Therefore the formulated hypothesis "There is significant difference found in patient's social support based on demographic variables" is accepted.

\section{Self-Esteem}

The results unveiled that patient's self-esteem differs by their age, gender, marital status, occupation and duration of illness (see Table 5). The average self-esteem was found to be $12.63,16.11$, and 16.19 for the age group of 20 to 35 years, 36 to 50 years, and above 50 years respectively. The findings infer that above 50 years old patients are having higher self-esteem than below 50 years old HIV/AIDS patients. Findings also illustrated that 36 to 50 years old
HIV/AIDS patients are having high self-esteem than 20 to 35 years' old patients. Robins, Trzesniewski, Tracy, Gosling, \& Potter (2002) also found the age difference in self-esteem. Simultaneously, Tiggemann \& Lynch (2001); Ranzijn, Keeves, Luszcz, \& Feather (1998) reported the same findings. Gove, Ortega, \& Style (1989) also found higher levels of self-esteem among old people.

Simultaneously the mean self-esteem was found 17.22, 14.19 , and 13.13 , for the employed, businessmen, and unemployed HIV/AIDS patients respectively. The significant $\mathrm{p}-$ value $(p<.001)$ reveals that patient's self-esteem differs by their occupation. The employed patients are having higher self-esteem than business doing and unemployed patients. Simultaneously, patients doing business have high selfesteem than unemployed patients. The present findings are in consonance with the findings of Azar \& Vasudeva (2006); Pishghadam, Bakhshipour \& Ebrahimi (2013) they reported employed people have higher self-esteem than unemployed and non-professionally employed.

The average self-esteem on the basis of their duration of illness was found $11.65,14.84,16.67$, and 19.89 for patients with less than 1 year, 2 to 4 years, 5 to 6 years, and more than 6 years duration of illness. Hence it is revealed that patients having more than 6 years duration of illness are having higher levels of self-esteem than those patients having less than 6 year duration of illness. The patients having 5 to 6 years duration of illness have higher levels of self-esteem than those patients having less than 5 year duration of illness respectively. Also, patients having 2 to 4 years duration of illness have higher self-esteem than those patients having less than 1 year duration of illness. 
Table 5. Mean, standard deviation, f-value, Eta-Square and post hoc of Self-Esteem by demographical variables of the HIV/ AIDS patients ( $N=460)$.

\begin{tabular}{|c|c|c|c|c|c|c|c|c|}
\hline Variable & Sub variables & $\mathrm{N}$ & Mean & S.D & f-value & $\mathrm{p}$-value & $\eta^{2}$ & post hoc \\
\hline & $20-35$ years $(a)$ & 192 & 12.63 & 6.02 & & & & \\
\hline \multirow{3}{*}{ Age } & $36-50$ years $(\mathrm{b})$ & 176 & 16.11 & 6.08 & \multirow{3}{*}{8.12} & \multirow{3}{*}{$<.001$} & \multirow{3}{*}{0.07} & \multirow{3}{*}{$\mathrm{c}>\mathrm{b}>\mathrm{a}$} \\
\hline & Above 50 years (c) & 92 & 16.19 & 6.64 & & & & \\
\hline & Employed (a) & 141 & 17.22 & 6.46 & & & & \\
\hline \multirow{4}{*}{ Occupation } & Businessmen (b) & 126 & 14.19 & 5.83 & \multirow{4}{*}{8.41} & \multirow{4}{*}{$<.001$} & \multirow{4}{*}{0.07} & \multirow{4}{*}{$a>b>c$} \\
\hline & Unemployed (c) & 193 & 13.13 & 6.16 & & & & \\
\hline & Less than 1 Year (a) & 123 & 11.65 & 6.44 & & & & \\
\hline & 2-4 Years (b) & 212 & 14.84 & 5.74 & & & & \\
\hline \multirow[t]{2}{*}{ Duration of Illness } & 5-6 Years (c) & 98 & 16.67 & 6.24 & \multirow[t]{2}{*}{0.76} & \multirow[t]{2}{*}{$<.001$} & \multirow[t]{2}{*}{0.12} & \multirow[t]{2}{*}{$\mathrm{d}>\mathrm{c}>\mathrm{b}>\mathrm{a}$} \\
\hline & More than 6 years $(\mathrm{d})$ & 27 & 19.89 & 5.23 & & & & \\
\hline
\end{tabular}

After the mean deviation and post hoc comparisons were made with self-esteem, the Cohen's effect size was calculated with eta square calculations (see Table 6). The eta square value $\eta^{2}=0.07,0.07$ and 0.12 for age, occupation and duration of illness respectively. All the values of eta square reveal a small magnitude of effect on self-esteem with all demographic variables.

Table 6. Mean, standard deviation, $\mathrm{t}-\mathrm{values}$, and Eta-square of Self-Esteem by demographical variables of the HIV/ AIDS patients (N=460).

\begin{tabular}{llcccccc}
\hline Variable & Sub variables & $N$ & Mean & $S D$ & $t$-value & $p$-value & $\eta^{2}$ \\
\hline \multirow{3}{*}{ Gender } & Male & 177 & 16.05 & 6.79 & \multirow{2}{*}{0} & $<.001$ & 0.03 \\
& Female & 283 & 13.82 & 5.98 & 3.96 & & \\
Marital Status & Married & 295 & 17.25 & 5.50 & & $<.001$ & 0.29 \\
\hline
\end{tabular}

The research also indicates that male and married AIDS patients have higher self-esteem than female and unmarried AIDS patients. For male and female HIV/AIDS patients, average self-esteem was found 16.05 and 13.8. For married it was found 17.25 and 10.07 for unmarried HIV/AIDS patients respectively. The significant $\mathrm{p}$-value $(p<.001)$ of both categories infers that self-esteem differs by gender as well as marital status. Hence the formulated hypothesis "There is significant difference found in patient's self-esteem based on demographic variables" is accepted. These findings also goes along with the study of done by Rashid, Bukhari, Fatima, Saba, \& Afzal, (2017); Quatman \& Watson (2001); Steitz \& Owen (1992); McMullin \& Cairney (2004) they also found women have lower self-esteem than men. Moreover, Hong, Bianca, Bianca, \& Bollington (1993) suggested that males have higher levels of self-esteem than females.

To know the level of effect the underlying variable have with one another, effect size devised by Cohen (1988) was calculated. The eta square here was found at $\eta^{2}=0.03$ and 0.29 for Gender and marital status which shows that there is small effect of gender and marital status on self-esteem.

\section{Quality of Life}

The result demonstrated that patient's quality of life differs by their age, marital status, occupation and duration of illness (see Table 7). The average quality of life (QoL) was found $67.99,77.69$, and 75.76 , for 20 to 35 years, 36 to 50 years, and above 50 year old patients. Patients 36 to 50 years of age are having higher quality of life than below 35 years and above 50 years old HIV/AIDS patients respectively. Further the research indicates that above 50 years old HIV/AIDS patients are having better quality of life below 35 years old patients. The findings are in line with those of previous research by Liping, Peng, Haijiang, Lahong \& Fan (2015) they reported that young patients have better quality of life. Pereira \& Canavarro (2011); Han, Park, Kim, Kim, \& Park (2014) also exposed that age influences quality of life. It is also divulged that older patients have lower, (Razavi et al., 2012); moderate (Astina, Ahmad, \& Budiyanto, 2015), and worse quality of life than younger one (Hays et al., 2000).

Table 7. Mean, standard deviation, f-value, Eta-square, and post hoc of Quality of Life by demographical variables of the HIV/ AIDS patients ( $N=460)$.

\begin{tabular}{|c|c|c|c|c|c|c|c|c|}
\hline$\overline{\text { Variable }}$ & Sub variables & $N$ & Mean & $S D$ & $F$-value & $p$-value & $\eta^{2}$ & post hoc \\
\hline & $20-35$ years (a) & 192 & 67.99 & 13.24 & & & 0.08 & \\
\hline \multirow{3}{*}{ Age } & $36-50$ years (b) & 176 & 77.64 & 14.82 & 22.42 & $<.001$ & & $b>c>a$ \\
\hline & Above 50 years $(\mathrm{c})$ & 92 & 75.76 & 15.75 & & & & \\
\hline & Employed (a) & 141 & 79.58 & 13.39 & & & 0.09 & \\
\hline \multirow[t]{3}{*}{ Occupation } & Businessmen (b) & 126 & 73.22 & 15.58 & 23.80 & $<.001$ & & $a>b>c$ \\
\hline & Unemployed (c) & 193 & 68.62 & 14.17 & & & & \\
\hline & Less than 1 Year (a) & 123 & 64.72 & 12.23 & & & 0.24 & \\
\hline \multirow[t]{3}{*}{ Duration of Illness } & 2-4 Years (b) & 212 & 71.71 & 14.01 & 49.08 & $<.001$ & & $\mathrm{~d}>\mathrm{c}>\mathrm{b}>\mathrm{a}$ \\
\hline & 5-6 Years (c) & 98 & 82.81 & 13.35 & & & & \\
\hline & More than 6 years $(d)$ & 27 & 89.29 & 7.67 & & & & \\
\hline
\end{tabular}


Likewise age, patient's quality of life differs by their occupation. Their average quality of life with respect to their occupation was found 79.58, 73.22, and 68.62, for the employed, businessmen, and unemployed patients. The employed AIDS patients are having better quality of life than business doing, and unemployed patients. Also patients doing business have better quality of life than unemployed patients. It is also reported by researchers that occupation significantly influences quality of life (Abasiubong, Ekott, Bassey, \& Etukumana, 2010) employment is associated with better quality of life (Reis, Santos \& Gir, 2012) and unemployed patients have lower quality of life than employed patients (Razavi et al., 2012).

Results uncovered that patients living with HIV/AIDS more than 6 years are having better quality of life than those of having duration of illness less than 6 year. Also patients having 5 to 6 years duration of illness have better quality of life than those patients having duration of illness less than 4 years respectively. The mean quality of life was found 64.72 , $71.71,82.81$, and 89.29 , for the HIV/AIDS patients with less than 1 year, 2 to 4 years, 5 to 6 years, and more than 6 years duration of illness respectively. Results also revealed that patients having 2 to 4 years duration of illness have better quality of life than those patients having less than 1 year duration of illness. Jufar, Nuguse, \& Misgn (2017); Lifson, Grandits, Gardner, Wolff, Pulik, Williams, \& Burman (2015); Mannheimer, Matts, Telzak, Chesney, Child, Wu, \& Friedland (2005) also verified that quality of life is significantly influenced by duration of illness.
Further the eta square for the quality of life variable was calculated pertaining to various demographic variables. The calculated eta square was found $\eta^{2}=0.08,0.09$ and 0.24 forage, occupation and duration of illness respectively. In all demographic variables it is obvious that there is a small magnitude of effect between age, occupation and duration of illness with regard to quality of life.

The research exposed that male and married have better quality of life than female and unmarried patients (see Table 8). Average quality of life of male and female patients was found 75.14 and 72.05. Similarly it was found to be 81.91 and 57.75 for the married and unmarried HIV/AIDS patients. Further the eta square to ascertain the effect size on quality of life by gender and marital status was evaluated which shows that there is small effect size of gender on social support $\left(\eta^{2}=0.09\right)$ while the effect size of marital status on quality of life is medium $\left(\eta^{2}=0.59\right)$. Tesfay, Gebremariam, Gerbaba, \& Abrha (2015); Nirmal, Divya, Dorairaj, \& Venkateswaran (2008) found that female have low quality of life than male. On the other side Tandon \& Sharma (2016); Astina, Ahmad, \& Budiyanto (2015); Hollywood, Hutchings, \& Dasgupta, (2014) reported not significant gender differences in quality of life. Simultaneously Imhonde \& Igboanusi (2008); Jufar, Nuguse, \& Misgn (2017) also reported that marital status is significantly influences the quality of life. Thereforeon the basis of these finding the third hypothesis "The$r e$ is significant difference found in patients quality of life based on demographic variables" is also accepted.

Table 8. Mean, standard deviation, $t$-values, and Eta-square of Quality of Life by demographical variables of the HIV/ AIDS patients $(N=460)$.

\begin{tabular}{|c|c|c|c|c|c|c|c|}
\hline Variable & Sub variables & $N$ & Mean & $S D$ & $t$-value & $p$-value & $\eta^{2}$ \\
\hline \multirow{3}{*}{ Gender } & Male & 177 & 75.14 & 14.61 & & 0.32 & 0.09 \\
\hline & Female & 283 & 72.05 & 15.21 & 2.14 & & \\
\hline & Married & 295 & 81.91 & 10.69 & & $<.001$ & 0.59 \\
\hline Marital Status & Unmarried & 165 & 57.75 & 7.17 & 25.93 & & \\
\hline
\end{tabular}

The fourth hypothesis "Significant relationship is found between the social support, self-esteem and quality of life" is also accepted as the positive relationship was found between the variable (see Table 9). Social support was found positively correlated with self-esteem $(r=.862, p<.01)$, and quality of life $(r$ $=.660, p<.01)$. Simultaneously, self-esteem is also positively related with quality of life $(r=.621, p<.01)$. Unsar, Erol, \& Sut (2016) also found positive correlations between quality of life score and social support. Devi \& Jyotsana (2016); Charkhian, Fekrazad, Sajadi, Rahgozar, Abdolbaghi, \& Maddahi (2014) and Bharathi, Pai \& Nayak (2014) also reported similar findings.

Table 9. Correlation Analysis

\begin{tabular}{|c|c|c|c|}
\hline & Social Support & Self-Esteem & Quality of Life \\
\hline Social Support & 1 & $.862 * *$ & $.660 * *$ \\
\hline Self-Esteem & & 1 & $.621 * *$ \\
\hline Quality of Life & & & 1 \\
\hline
\end{tabular}

\section{Discussion}

The above description of results revealed and interpreted different aspects and dimensions of the present investigation. The present research study focused on various elements pertaining to the HIV AIDS based on the research gap that has been identified through relevant review of literature. The study results in relation to social support and self-esteem supports the early findings that both self-esteem and social support play an important role in fighting this disease. The study revealed that patients above the age of 50 years are having higher levels of self-esteem while patients of lower age groups show lower levels of self-esteem. The same is true with regard to level of support available to patients of HIV/AIDS. The study results also supports the early research conducted by Rigby \& Slee (1999) where they found that patients having low social support available are more 
vulnerable to suicide and depression. This study also supported the findings provided by Wani \& Sankar (2017) and Adewuya et al., (2007) that there exists a negative relationship between social support and suicidal ideation and other psychological problems. The present study is in compliance with the early research studies and the results support this idea that to improve the overall well-being of patients living with HIV/AIDS we need to improve the level of self-esteem and social support. The higher levels of social support gives a patient self of belongingness and a feeling of love and affection, the patients can cope psychologically better with the disease as compared to people with lower levels of social support and self-esteem.

The study also aimed to find the quality of life of HIV/AIDS patients where it was found that patients between the 36 to 50 years of age are having higher quality of life than above 50 years old HIV/AIDS patients. The findings are in line with those of previous research by Liping, Peng, Haijiang, Lahong \& Fan (2015) they reported that young patients have better quality of life. Pereira \& Canavarro (2011); Han, Park, Kim, Kim, \& Park (2014) also exposed that age influences quality of life. It is also divulged that older patients have lower, (Razavi et al., 2012); moderate (Astina, Ahmad, \& Budiyanto, 2015), and worse quality of life than younger one (Hays et al., 2000).

\section{Conclusion}

To sum up, taking into account the results of the present study, it is concluded that majority of HIV/AIDS patients are living with lower social support, low self-esteem, and poor quality of life. Patient's social support and self-esteem significantly differ by their gender, marital status, age, occupation, and duration of illness. However the quality of life differs by marital status, age, occupation, and duration of illness respectively. Further positive relationship was found between independent and dependent variables.

\section{References}

Abasiubong, F., Ekott, J. U., Bassey, E. A., \& Etukumana, E. A. (2010). Quality of life in people living with HIV/AIDS in Niger delta region. Nigeria Journal of Mental Health, 19 (2), 211-218.doi: 10.3109/09638230903469210

Adewuya, A. O., Afolabi, M. O., Ola, B. A., Ogundele, O. A., Ajibare, A. O., \& Oladipo, B. F. (2007). Psychiatric disorders among the HIV positive population in Nigeria: a control study. Journal of Psychosomatic Research, 63(2), 203-206. doi:10.1016/j.jpsychores.2007.03.006

Astina, I. K., Ahmad, W. I., \& Budiyanto, B. (2015). Quality of life of older persons in Indonesia: Sex differences. Mediterranean Journal of Social Sciences, 6(3), 3113-317. doi:10.5901/mjss.2015.v6n3s2p313

Azar, I. A., \& Vasudeva, P. (2006). Self efficacy and self-esteem: A comparative study employed and unemployed married women in Iran, German Journal of Psychiatry, 9(3), 111-117.

Bennett, S. J., Perkins, S. M., Lane, K. A., Deer, M., Brater, D. C., \& Murray, M. D. (2001). Social support and health related quality of life in chronic heart failure patients, Quality of Life Research 10(8), 671-682. doi: 10.1023/a: 1013815825500

\section{Limitations of the study}

The present study was conducted in Jammu and Kashmir State and only registered patients in ART center SKIMS Srinagar and GMC Jammu were taken in the study. Therefore, the researcher cannot reach to unregistered patients, and those who live in rural areas particularly near to line of control. Cause of illness was not known because researcher was not allowed to ask such questions by the authority

\section{Suggestions}

$\mathrm{By}$ the research it is to be suggested that awareness and information regarding HIV/AIDS should be incorporated with curriculum of school, college and university levels. Public awareness regarding cause and preventive methods should be held at local levels. Village Panchayats and municipal committees should be used to serve this purpose. Further better health care facilities are the important provision in minimizing the effect of this disease. Government and non government organizations should provide better social environment to people living with HIV/AIDS so they would not feel isolated. Proper psychological counselling should be given to them on regular basis to avoid any sort of negative psychological impact. It would improve their quality of life and enhance their self-esteem. Also comprehensive rehabilitation centers should be developed, where skill based training is given to such patients, so that they may don't feel dejected and burden to society.

Acknowledgement.-It is my obligatory duty to offer my joyful gratitude to all those HIV/AIDS and other people who extended their full support and cooperation during the data collection. I feel honored to extend my gratitude to director JKSACS and in charge doctors from ART center SKIMS Srinagar and GMC Jammu for the permission to collect data in their respective centers.

Bharathi, Pai, M. S., \& Nayak, B. S. (2014). Quality of life and social support among children living with HIV in south India. Journal of Nursing and Health Science, 3(6), 55-58. doi: 10.9790/1959-03625558

Castrighini, C., Gir, E., Neves, L., Reis, R., Galvão, M., \& Hayashido, M. (2010). Depression and self-esteem of patients positive for HIV/AIDS in an inland city of Brazil. Retrovirology,7 (Suppl 1). doi: 10.1186/17424690-7-s1-p66

Cechim, P. L., \& Selli, L. (2007). Mulheres com HIV/AIDS: fragmentos de sua face oculta. Revista Brasileira de Enfermagem, 60(2), 145-149. doi:10.1590/s0034-71672007000200004

Charkhian, A., Fekrazad, H., Sajadi, H., Rahgozar, M., Abdolbaghi, M, \& Maddahi, S. (2014). Relationship between health related quality of life and social support in HIV infected people in Tehran, Iran. Iranian Journal of Public Health, 43(1), 100-106.

Cobb, S. (1976). Social support as a moderator of life stress. Psychosomatic Medicine, 38, 300-314

Cohen, J. (1988). Statistical power analysis for the behavioral sciences. Hillsdale, NJ:Erlbaum. 
Debra, A. M., \& Barbara, A. (2000). Psychological distress among HIV positive adolescents in the reach study: effects of life stress, social support, and coping. Journal of Adolescent Health,27(6), 391-398. doi: 10.1016/S1054-139X (00)00158-0

Denissen, J. J., Penke, L., Schmitt, D. P., \& Aken, M. A. (2008). Self-esteem reactions to social interactions: Evidence for sociometer mechanisms across days, people, and nations. Journal of Personality and Social Psychology,95(1), 181-196. doi:10.1037/0022-3514.95.1.181

Devi, S., \& Jyotsana (2016). Identity formation: Role of social support and self esteem among Indian adolescents. International Journal of Indian Psychology, 3 (2, 4), 114-124.

Gove, W. R., Ortega, S. T., \& Style, C. B. (1989). The maturational and role perspectives on aging and self through the adult years: An empirical evaluation. American Journal of Sociology, 94(5), 1117-1145. doi:10.1086/229113

Han, K., Park, E., Kim, J., Kim, S. J., \& Park, S. (2014). Is marital status associated with quality of life? Health and Quality of Life Outcomes, 12(1). doi:10.1186/s12955-014-0109-0

Hays, R. D., Cunningham, W. E., Sherbourne, C. D., Wilson, I. B., Wu, A. W., Cleary, P. D., . . . Bozzette, S. A. (2000). Health-related quality of li$\mathrm{fe}$ in patients with human immunodeficiency virus infection in the United States: results from the HIV cost and services utilization study. The American Journal of Medicine, 108(9), 714-722. doi: 10.1016/s0002-9343(00)00387-9

Hollywood, J., Hutchings, A., \& Dasgupta, B. (2014). Gender differences in health related quality of life in Polymyalgia Rheumatica. Rheumatology,53 (Suppl 2), I14 doi:10.1093/rheumatology/keu210.007

Hong, S., Bianca, M. A., Bianca, M. R., \& Bollington, J. (1993). Self-Esteem: The Effects of Life-Satisfaction, Sex, and Age. Psychological Reports, 72(1), 95-101. doi:10.2466/pr0.1993.72.1.95

Imhonde, H., \& Igboanusi, O. (2008). Influence of social support, duration of illness and age on quality of life among breast cancer patients. IFE PsychologLA, 16(2), 91-100. doi:10.4314/ifep.v16i2.23803

J\&KSACS (2017). Detail of HIV Clients till August 2017 (ART, Jam$\mathrm{mu} /$ Srinagar). Assessed from http://www.jksacs.org/art.php on 05-112017 at $3.20 \mathrm{pm}$

Jufar, A. H., Nuguse, F. G., \& Misgn, H. G. (2017). Assessment of health related quality of life and associated factors among hypertensive patients on treatment at public hospitals in Mekelle, North Ethiopia. Journal of Hypertension, 6(1), 1000239. doi: 10.4172/2167-1095.1000239

Khurana, P. (1989). AIDS humanity's gravets challenge. (pp. 34-40). Hind Pocket Books, Connaught Place, New Delhi:

Kong, F., Perrucci, C. C., \& Perrucci, R. (1993). The impact of unemployment and economic stress on social support. Community Mental Health Journal, 29(3), 205-221. doi:10.1007/bf00778807

Lifson, A., Grandits, G., Gardner, E., Wolff, M., Pulik, P., Williams, I., \& Burman, W. (2015). Quality of life assessment among HIV-positive persons entering the INSIGHT strategic timing of antiretroviral treatment (START) trial. HIV Medicine, 16, 88-96. doi:10.1111/hiv.12237

Liping, M., Peng, X., Haijiang, L., Lahong, J., \& Fan, L. (2015). Quality of life of people living with HIV/AIDS: A cross sectional study in Zhejiang province, China. PLoS ONE, 10(8): e0135705. doi: 10.1371/ journal.pone.0135705

Mannheimer, S. B., Matts, J., Telzak, E., Chesney, M., Child, C., Wu, A. W., \& Friedland, G. (2005). Quality of life in HIV-infected individuals receiving antiretroviral therapy is related to adherence. AIDS Care, 17(1), 10-22. doi: 10.1080/09540120412331305098

Mcmullin, J. A., \& Cairney, J. (2004). Self-esteem and the intersection of age, class, and gender. Journal of Aging Studies, 18(1), 75-90. doi:10.1016/j.jaging.2003.09.006

Moksnes, U. K., \& Espnes, G. A. (2013). Self-esteem and life satisfaction in adolescents' gender and age as potential moderators. Quality of Life Research, 22(10), 2921-2928. doi: 10.1007/s11136-013-0427-4

Nakimuli, M. E., Musisi, S., Katabira, E., Nachega, J., \& Bass, J. (2011). Prevalence and factors associated with depressive disorders in an HIV+ rural patient population in southern Uganda. Journal of Affective Disorders, 135(1-3), 160-167. doi: 10.1371/journal.pone.0181960

Nirmal, B., Divya, K., Dorairaj, V., \& Venkateswaran, K. (2008). Quality of life in HIV/AIDS patients: A cross-sectional study in south India. Indian Journal of Sexually Transmitted Diseases and AIDS, 29(1), 15. doi:10.4103/0253-7184.42708
Nunes, J. A., Raymond, S. J., Nicholas, P. T., \& Webster A. (1995). Social support, quality of life, immune function, and health in persons living with HIV. Joumal of Holistic Nursing, 13(2), 174-198.doi 10.1177/089801019501300207

Pereira, M., \& Canavarro, M. C. (2011). Gender and age differences in quality of life and the impact of psychopathological symptoms among HIV infected patients.AIDS and Behavior, 15(8), 1857-1869. doi: 10.1007/s10461-0119928-8

Pishghadam, M., Bakhshipour, B. A., \& Ebrahimi, S. (2013). Self-esteem comparison between employed and non-employed women of Tehran city. Journal of Novel Applied Sciences, 2 (S), 787-790

Quatman, T., \& Watson, C. M. (2001). Gender differences in adolescent self-esteem: An exploration of domains. The Journal of Genetic Psychology, 162(1), 93-117. doi: 10.1080/00221320109597883

Rani, K., E. (2016). Perceived social support and psychological well-being: testing the unique association and gender differences among young working adults. International Journal of Indian Psychology, 3 (2, 4), 97-113.

Ranzijn, R., Keeves, J., Luszcz, M., \& Feather, N. T. (1998). The role of self-perceived usefulness and competence in the self-esteem of elderly adults: Confirmatory factor analyses of the Bachman revision of Rosenberg's self-esteem scale. The Journals of Gerontology Series B: Psychological Sciences and Social Sciences, 53B (2), 96-104. doi:10.1093/geronb/ 53b.2.p96

Rashid, A., Bukhari, S. R., Fatima, S. I., Saba, F., \& Afzal, F. (2017). Selfesteem among male and female Adolescents, International Journal of In dian Psychology, 4(3), 73-78.

Razavi, P., Hajifathalian, K., Saeidi, B., Djavid, G. E., Rasoulinejad, M., Hajiabdolbaghi, M., . . . Mcfarland, W. (2012). Quality of life among persons with HIV/AIDS in Iran: internal reliability and validity of an international instrument and associated factors. AIDS Research and Treatment, Article ID 849406, doi:10.1155/2012/849406

Reis, R. K., Santos, C. B., \& Gir, E. (2012). Quality of life among Brazilian women living with HIV/AIDS. AIDS Care, 24(5), 626-634 doi:10.1080/09540121. 2011.630345

Reis, R. K., Santos, C. B., Dantas, R. A., \& Gir, E. (2011). Qualidade de vi$\mathrm{da}$, aspectos sociodemográficos e de sexualidade de pessoas vivendo com HIV/AIDS. Texto \& Contexto Enfermagem,20(3), 565-575. doi:10.1590/s0104-07072011000300019

Reza, I. M., \& Siddegowda, Y. S. (2010). Social support among Iranian women: influence of age and occupation. Asian Journal of Development Matters, 4(1), 204-210.

Riaz, M., Abid, M., Ullah, N., \& Khalid, S. (2016). A study on social support and stress among married women school teachers. International Journal of Emergency Mental Health and Human Resilience, 18(4), 1-3. doi:10.4172/ $1522-4821.1000348$

Rigby, K., \& Slee, P. (1999). Suicidal ideation among adolescent school children, involvement in bully victim problems, and perceived social support, Suicide and Life Threatening Behavior, 29(2), 119-130. doi: 10.1111/j.1943-278X.1999.tb01050.x

Roberts, H., Pearson, J. C., Madeley, R. J., Hanford, S., \& Magowan, R. (1997). Unemployment and health: the quality of social support among residents in the Trent region of England. Journal of Epidemiology \& Community Health, 51(1), 41-45. doi:10.1136/jech.51.1.41

Robins, R. W., Trzesniewski, K. H., Tracy, J. L., Gosling, S. D., \& Potter J. (2002). Global self-esteem across the life span. Psychology and Aging, 17(3), 423-434. doi: 10.1037//0882-7974.17.3.423

Rom, W. N., \& Markowitz, S. (2011). Environmental and Occupational Medicine. Philadelphia: Wolters Kluwer Health, p. 745.

Sharir D., Tanasescu M., Turbow D. \& Maman Y. (2007). Social support and quality of life among psychiatric patients in residential homes. Inter national Journal of Psychosocial Rehabilitation.11(1), 81-91.

Shin, S. (2011). A study on health related quality of life in people living with HIV/AIDS in Korea. Health and Social Welfare Review, 31(4), 424-453. doi: 10.15709/hswr.2011.31.4.424

Steitz, J. A., \& Owen, T. P. (1992). School activities and work: Effects on adolescent self esteem. Adolescence, 27(105), 37-50.

Tandon, J., \& Sharma, R. (2016). Psychological distress and quality of life in male and female caregivers of schizophrenics, International Journal of In dian Psychology, 3(4, 67), 147-157. 
Tesfay, A., Gebremariam, A., Gerbaba, M., \& Abrha, H. (2015). Gender differences in health related quality of life among people living with HIV on highly active antiretroviral therapy in Mekelle Town, Northern Ethiopia. Bio Med Research International, Article Id 516369, doi: $10.1155 / 2015 / 516369$

Tiggemann, M. and Lynch, J.E. (2001) body image across the life span in adult women: The role of self objectification. Developmental Psychology, 37, 243-253. doi:10.1037/0012-1649.37.2.243

Unsar, S., Erol,O., \& Sut, N. (2016). Social support and quality of life among older adults. International Journal of Caring Sciences, 9(1), 249-257.

Van, D. A. C. (2008). HIV AIDS care \& counselling: a multidisciplinary approach (4th ed.). Cape Town: Pearson Education South Africa.

Wani, M. A. (2018). Quality of life among people living with HIV/AIDS in Jammu \& Kashmir. Journal of HIV/AIDS Research and Therapy, 1, 1-5. doi: http://doi.org/04.2018/1.10002
Wani, M. A., \& Sankar, R. (2017). Social support, self-esteem and suicidal ideation among HIV/AIDS patients in Jammu and Kashmir State. Indian Journal of Health and Wellbeing, 8(9), 944-949

Wani, M. A., \& Sankar, R. (2017a).Social support, quality of life and suicidal ideation among people living with HIV/AIDS in ART center Jammu. Indian Journal of Positive Psychology, 8(3), 300-305.

Wani, M. A., \& Sankar, R. (2017b). Impact of social support on quality of life among AIDS patients in Kashmir province of Jammu and Kashmir, India. Journal of AIDS \& Clinical Research 8(9), 729. doi: 10.4172/21556113.1000729

WHO (2017). HIV/AIDS Fact sheet July. Assessed from http://www.who.in /mediacentre/factsheets/fs360/en/ on 16-082017 at $2.35 \mathrm{pm}$. 